\title{
波と流れを受ける直立型水車のエネルギー変換効率に関する研究
}

\section{Energy conversion efficiency of a vertical water turbine under combined actions of wave and current}

\author{
中村孝幸 ${ }^{1}$ ・ 阿部洋士 ${ }^{2} \cdot$ Firman Husain $^{3}$ \\ Takayuki NAKAMURA, Hiroshi ABE and Firman HUSAIN
}

\begin{abstract}
We have shown that the conversion efficiency of tidal current energy by a vertical Savonius water turbine is significantly improved by introducing a new guide vane device around it. In the target site of a tidal current power plant, typically Kurushima Strait in the Seto Inland Sea, the site usually faces to comparatively wide sea area on both sides of the narrow channel. Therefore, wave actions on the tidal current power plant must be examined from both the points of structural stability and energy conversion efficiency. In this study, the influence of wave actions on the conversion efficiency of tidal energy was examined experimentally through the use of combined flow field of waves and tidal currents. In addition, effectiveness of a vertical Savonius water turbine as a wave energy extraction device was also examined.
\end{abstract}

\section{1. はじめに}

既に著者らの中の一人は (中村ら, 2011 ; 井内ら, 2012), 上げ潮と下げ潮で流れが逆転するなどの潮流特性を踏ま えて, 流向依存性が少ない直立型水車で構成される潮流 エネルギー変換装置を提案した。この際，水車起動のた めの初動水流速度が低く, 回転卜ルクが大きいなどの利 点を有するサボニウス式水車を採用すると共に，エネル ギー変換効率が低いという久点を改善するため, 水車の 周辺に流向制御板を配置した増速装置を付加する工法を 新たに開発し，その有効性などを明らかにしてきた。

一方, 海峡部は，その両側において比較的広い海域へ と接続することが多く, 潮流のみならず波の作用も受け やすいため, 潮流発電装置の効率に及ぼす波の影響につ いても検討する必要がある。本研究は, 最初に増速装置 つきの直立型サボニウ式水車を潮流発電装置㧍よび波力 発電装置として用いるときの有効性を実験的に明らかに する．また，潮流のみならず波の作用を受けるときの工 ネルギー変換効率についても検討を行い, 潮流発電装置 に及ぼす波の副次的な作用についても明らかにする。こ の際，並列配置された直立型サボニウス式水車による波 浪制御効果についても検討する。

\section{2. 実験概要}

\section{（1）実験水槽}

本実験には, 愛媛大学工学部の造波機付きの回流水槽を 用いた。この水路は, 図-1に示す規模で, その一端にピス トン型造波装置が設置してあり，両端部を大口径パイプで 結合してその途中に循環用の直流ポンプ3台が設けてある.

$\begin{array}{ll}1 \text { 正会員 工博 } & \begin{array}{l}\text { 愛媛大学大学院教授 理工学研究科 } \\ \text { 爱大学大学院 理工学研究科 } \\ 3\end{array} \\ \text { 愛媛大学大学院 理工学研究科 }\end{array}$

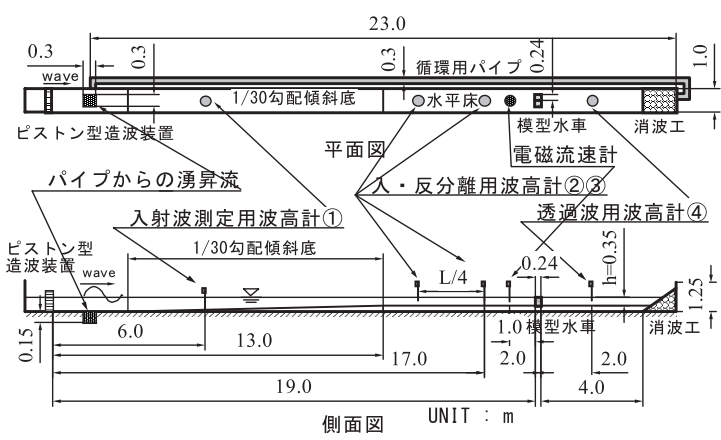

図-1 実験水槽

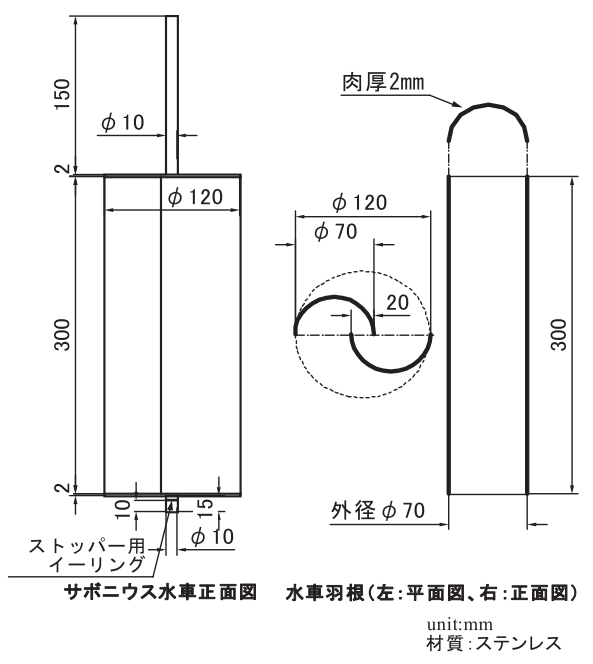

図-2 サボニウス水車

このため，水路内では一方向流と波を同時に発生させ て各種の水理実験が行えるようにしてある。他端には，再 反射を防ぐと共に水流の通水性を高めるためへチマロン よりなる消波工を設置した。水路内には $1 / 30$ 勾配の斜面 


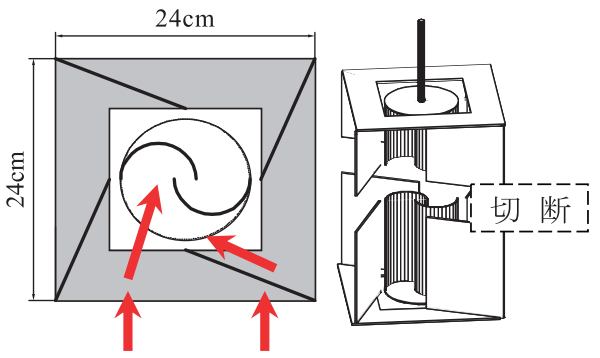

図-3 渦流型流向制御板

を設け，これに滑らかに接続するように高さ $40 \mathrm{~cm}$ の水 平床が設置してある. 後述する模型水車は, 図中に示す ようにこの水平床上に二基並列配置で設置した。潮流の 模型化には，フルードの相似則を用いることとし，模型 スケールを $S=1 / 20$ 程度に設定した。

\section{（2）模型水車と流向制御板}

本実験で用いた水車は，図-2に示す直立型サボニウス 式水車であり, 羽根部分の直径は $12 \mathrm{~cm}$, その高さは 30 $\mathrm{cm}$ である。これまでの研究（中村ら，2011; 井内ら， 2012）に基づき，水車の周りに流向制御板からなる増速 装置を取り付けると潮流エネルギーの取得率が大幅に改 善されることが判明しており，本研究でも同様の増速装 置を取り付けることとした。この装置は，図-3に示すよ うに4枚の鉛直板で構成される流向制御板（渦流型流向制 御板）で, 水車の外周に設置して支持壁を兼ねる構造と してある，実験では，増速装置付きの水車は，図-4に示 すように，両側に開口部を設け水路中央に二基並列に配 置した.

\section{(3) 実験条件}

実験で用いた水深 $h$ は $35 \mathrm{~cm}$ ，流速は最大出水能力に相 当する $0.3 \mathrm{~m} / \mathrm{s}$ 程度とした。作用波は規則波として，その 周期 $T$ は $1.2 \mathrm{~s}, 1.6 \mathrm{~s}, 2.0 \mathrm{~s}$ の3 種類とし, 入射波高 $H$ は 5 $\mathrm{cm}, 10 \mathrm{~cm}$ 程度の 2 種類とした.

実験ケースは，i）水車に波のみが作用する場合，ii）水 車に流れのみが作用する場合，iii）水車に波と流れが同時 に作用する場合の3ケースとした。

\section{(4) 計測方法}

実験では，図-4に示すように，直立型水車を上下端に 設けたボールベアリング軸受けにより摩擦が少なくなる ように支持すると共に上部軸受に接続する形式でトルク メーターに，またその上に発電機の負荷を近似的に与え るための磁気ブレーキへと弾性連結した。そして，この 装置により磁気ブレーキによる負荷トルクを各種に変化 させることで水車の回転数及び仕事率などを測定した．な お, 装置数の関係上, 隣接する他基の水車には負荷を作 用させることなく自由回転の状況で行った。

波高測定は，4台の容量式波高計を図-1に示すように配

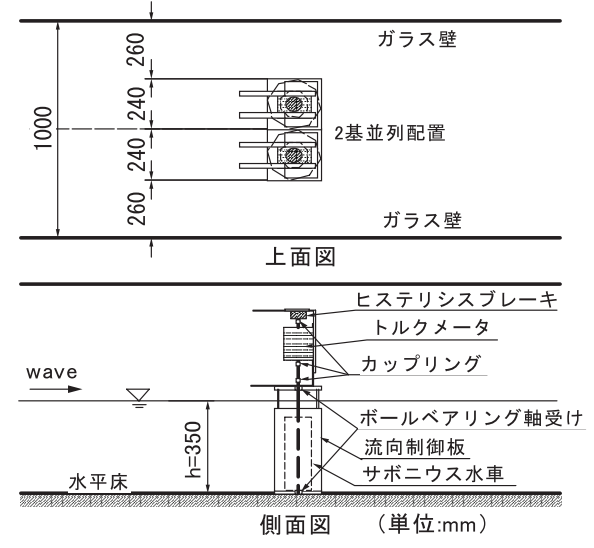

図-4 計測機の設置状況

置して実施した。具体的には，模型水車の沖側に入射波 測定用に 1 台，入・反射波分離用に 2 台，模型水車の岸側 に透過波測定用に 1 台とした。ここで，反射波は，入・反 射波分離用の波高計の測定值を用いて，合田ら（1976）の 入・反射波の分離推定法を用いて求めた。

流速測定には，水平・鉛直 2 方向の電磁流速計を用い, これを水車の上流側 $1 \mathrm{~m}$ の位置で水深中央に設置した.

\section{3. 水車の性能評価のための指標}

水車の性能を示す指標として動力係数 $C_{P}$ とトルク係数 $C_{T}$ がある. これらはそれぞれエネルギー変換効率および 回転動力を表し, 水車の回転速度を表す指標である周速 比 $\lambda$ 関数であることが知られている(例えば牛山, 2002). これら係数は次式の定義による.

$$
\begin{aligned}
& C_{P}=\frac{T_{t} \omega}{\frac{1}{2} \rho u^{3}(B d)+\frac{1}{8} \rho g H^{2} C_{g} B} . \\
& C_{T}=\frac{T_{t}}{\frac{1}{2} \rho\left(u+u^{\prime}\right)^{2}(2 R d) R} \ldots \ldots . . \\
& \lambda=\frac{R \omega}{u}, \quad \lambda^{\prime}=\frac{R \omega}{u^{\prime}}, \quad \lambda^{\prime \prime}=\frac{R \omega}{u+u^{\prime}}
\end{aligned}
$$

ここで, $T_{t}$ : 発電機による負荷トルクで, 実験では制御し やすい磁気ブレーキにより擬似的に与えた負荷, $\omega$ ：水車の 回転角速度, $\rho$ : 流体の密度, $u$ : 潮流速, $B$ : 増速装置の幅, $d:$ 水車の高さ, $g$ : 重力加速度, $H$ : 波高, $C_{g}$ : 群速度, $u^{\prime}$ : 線形波動理論による水面における水粒子水平速度の振幅, $R$ : 水車の半径である. また，以下の検討で，周速比は式 （3）で示すように，流れのみが作用するときの入，波のみ が作用するときの $\lambda$, , 両者が作用するときの $\lambda$ ” の 3 種類 で定義した。

波と流れが同時に作用する場合のエネルギー変換効率 の推定に際して, 本研究では流体運動の入力パワーは, 流 れと波のパワーの線形和で与えられるものと仮定した. 同 


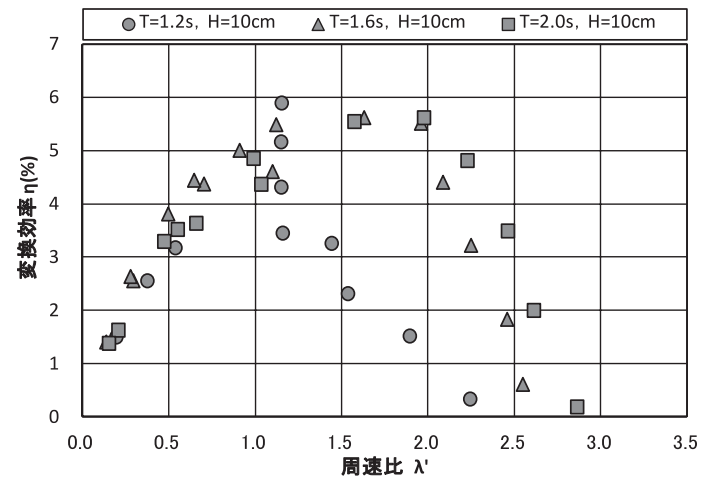

図-5 波が作用するときの変換効率

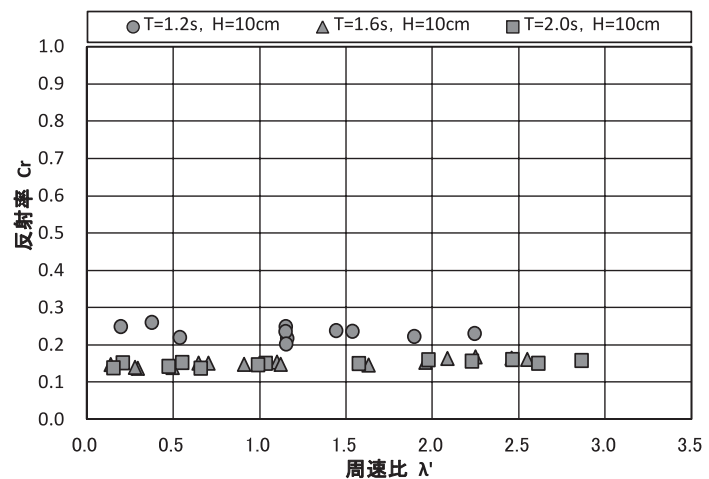

図-6＼cjkstart波が作用するときの反射率

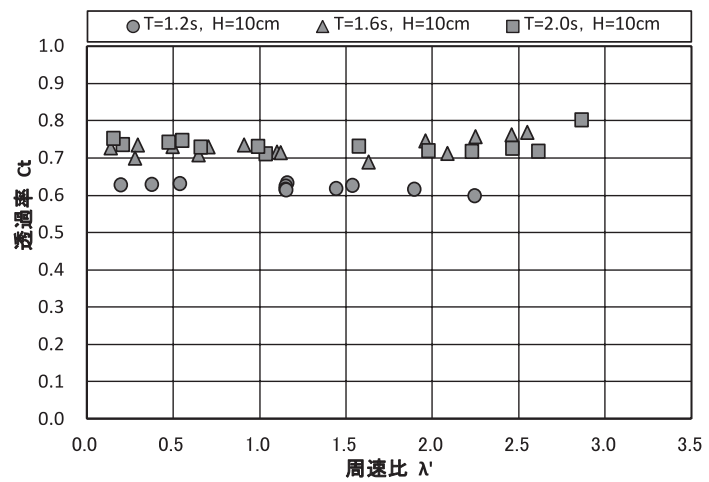

図-7＼cjkstart波が作用するときの透過率

様に，トルク係数，周速比の算定においても，主流速は 一方向流速と波運動による水面位置に扔ける水平水粒子 速度の振幅の線形和で与えられるものとした.

\section{4. 実験結果}

（1）波のみが作用する場合

図-5は，水車に波のみが作用するときのエネルギー変 換効率を周速比による変化で示す．変換効率はいずれの 周期条件でも $6 \%$ 以下であり，増速装置を付加する工法は
波力発電にはそれほど効果が認められない。

図-6は，並列水車による反射率 $C r$ を，図-7は，透過率 $C t$ を各作用波の条件について周速比による変化で示す. $T=1.2 \mathrm{~s}$ と短周期の条件では, 反射率が増大, 透過率が減 少する傾向が見られるが，並列配置水車の左右の開口率 が大きい（50\%程度）ため，その影響が卓越して現れる 傾向にある．また，各周期に扮ける周速比の変化による 反射・透過率に大きな差が見られないことから，反射・ 透過率は，水車の回転状況にほとんど影響されていない ものと判断される.

\section{（2）流れのみが作用する場合}

図-8 抢よび図-9は，渦流型流向制御板の有効性について 事前の実験により検討した結果である（中村ら，2013）。 図-8は，水車単独の場合と水車の周囲に渦流型流向制御 板を設置した場合のエネルギー変換効率と周速比の関係 を，図-9は，水車単独の場合と水車の周囲に渦流型流向 制御板を設置した場合のトルク係数と周速比の関係を示 す．実験では水路幅 $50 \mathrm{~cm}$ ，主流速は約 $0.4 \mathrm{~m} / \mathrm{s}$ としてあ り，現地量に換算すると来島海峡の年間平均流速の $2.5 \mathrm{~m} / \mathrm{s}$ に匹敵する. 図-8から，サボニウス水車単独の変換効率 は15\%程度と低いが，渦流型流向制御板を取り付けるこ

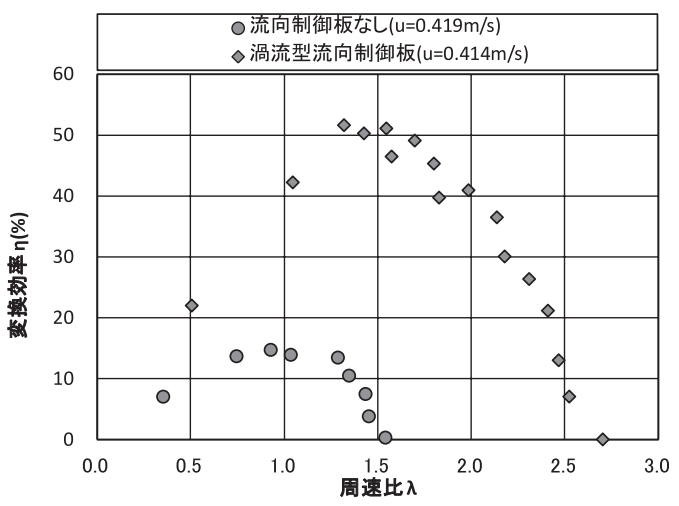

図-8 渦流型流向制御板の有無による変換効率の比較

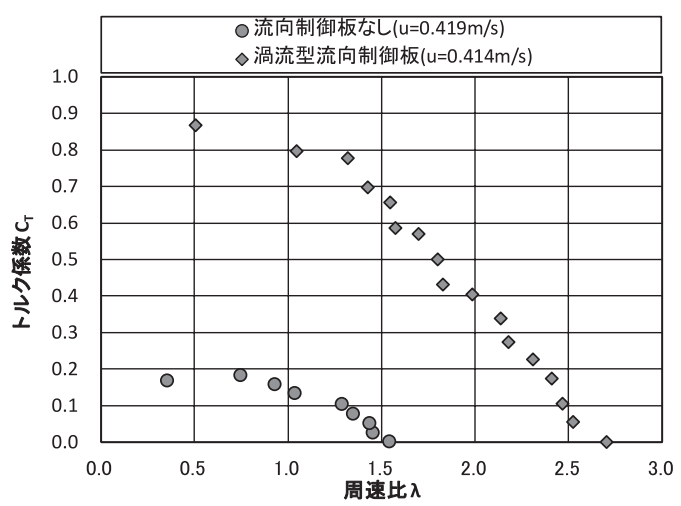

図-9 渦流型流向制御板の有無によるトルク係数の比較 


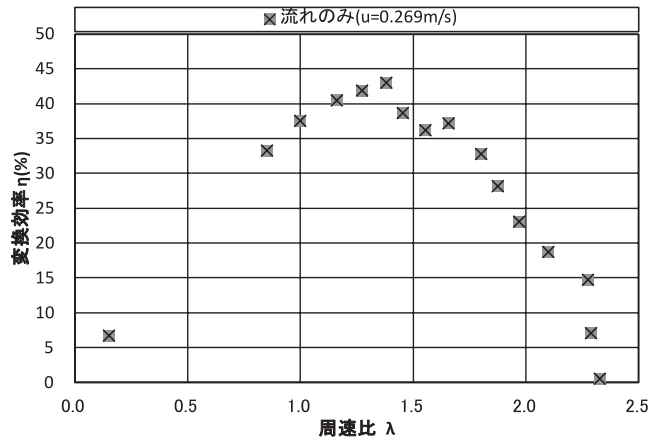

図-10＼cjkstart流れが作用するときの変換効率

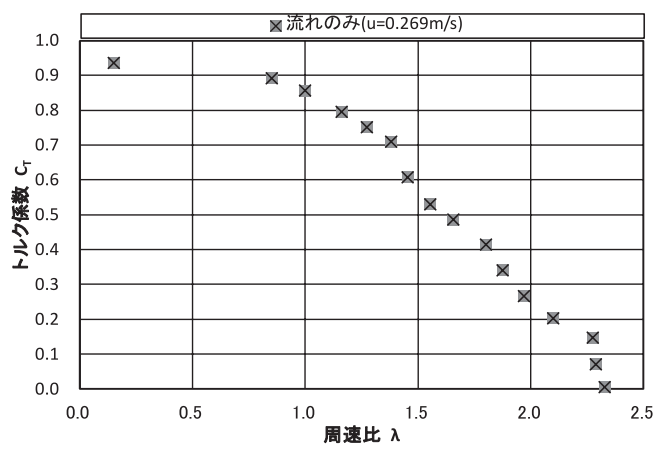

図-11＼cjkstart流れが作用するときのトルク係数

とで3倍以上の $50 \%$ 程度に改善され，潮流エネルギーの取 得効率が大幅に向上することが分かる．また，図-9より， 渦流型流向制御板を導入することで，トルク係数は，単 独水車の 4 倍以上の值を示すなど，回転力が有意に向上す るため, 潮流発電の高効率化において効果的であること が認められる。

図-10は，水車に流れのみが作用するときのエネルギー 変換効率を, 図-11は, 同様のときのトルク係数を周速比 による変化で示す．変換効率は最大で $45 \%$ 程度, トルク 係数は 0.9 を示し, 渦流型流向制御板を付加したサボニウ ス水車は潮流発電装置として優れた性能を示すことが分 かる. 図-8に示す過去の結果と比較して, 変換効率が多 少ながら低下した原因としては，ポンプ能力の限界から 水流速度が約 $1 / 2$ 程度と低下したことと, この水流速度の 低下による水車軸受け等の摩擦の影響が拡大して現れや すくなったことによるものと考えている.

\section{（3）波と流れが作用する場合}

図-12 は，磁気ブレーキによる負荷トルク $0.05 \mathrm{Nm}$ のと きのサボニウス水車にi）流れのみ，ii）波と流れを同時に 作用させた時の水車の回転数の時系列波形と平均回転数の 測定結果を示す．流れのみが作用する時と比較して，波と 流れを同時に作用させたときの方が水車の平均回転数およ び回転数の変動が大きくなる傾向が認められる．この傾向 は，波峰と波谷の位相時に波運動による水粒子水平速度が
極大および極小となることから，波峰時には波と流れの流 速が加算されて回転数が増大，波谷時には減算されて回転 数が減少することによるものと推測される，ただし，波谷 位相でも, 水車背面側では水車の回転を加速するように流 体力が作用するため, 平均的には増速傾向になるものと考 えられる. 以上より, 潮流により回転している増速装置付 き水車に対して，波が作用するときの影響は，全体的には 加算するように現れることが分かる.

図-13は，水車にi）流れのみ，ii）波と流れが同時に作 用するときの変換効率を周速比による変化で示す，波と 流れが同時に作用する時のエネルギー変換効率は, 流れ のみが作用する時の $1 / 3$ 以下と, エネルギー変換効率が著 しく低下し，作用波高が大きいほど変換効率は低下する 傾向が確認される。これは, 波高の増大に伴い, 波エネ ルギーが波高の二乗に比例して増大することが関係して いる. すなわち, 変換効率を求める際, 水車がなす仕事 率を波と流れのエネルギー流束の線形和で除することに より算定しており，波高増大に見合う仕事率の増加が現 れないため, 変換効率が低下する結果になったものと推 測される. 図-14は, 同様の条件下でのトルク係数の結果 を示す，波の影響を考慮すると，流れのみが作用する場 合と比較して，変換効率と同様，やはりトルク係数も著

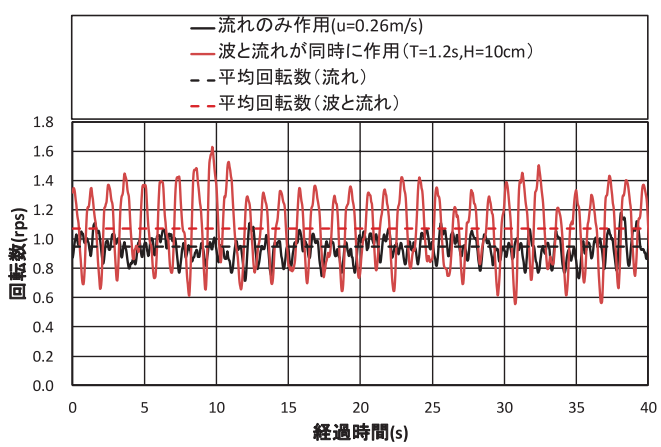

図-12 サボニウス水車に流れあるいは波と流れが同時に作用 するときの水車回転数の時間的な変化

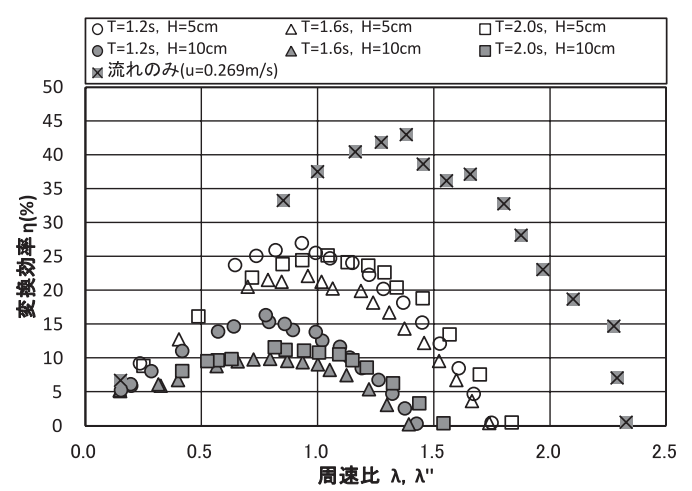

図-13 波と流れが作用するときの変換効率（波のエネルギー フラックス考慮) 


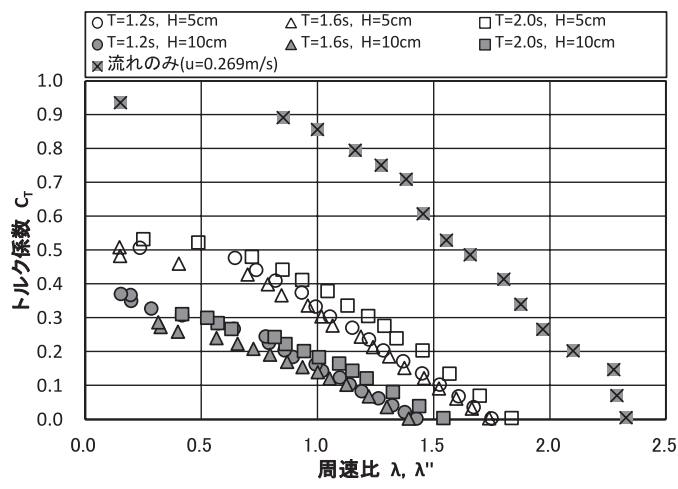

図-14 波と流れが作用するときのトルク係数（波による水平 水粒子速度振幅を考慮)

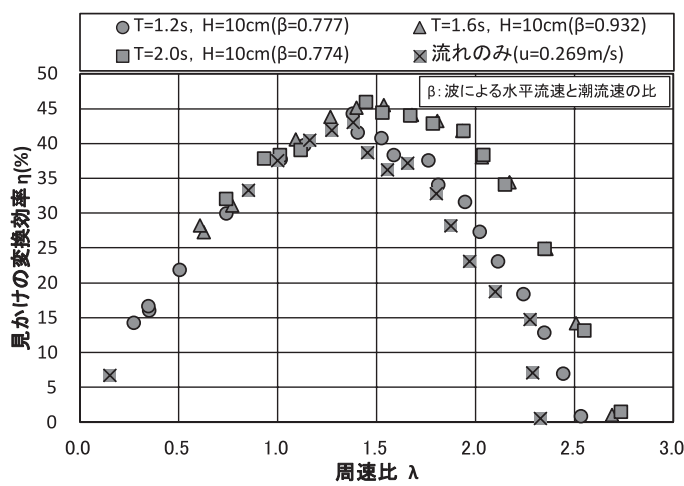

図-15 波と流れが作用するときの変換効率（波のエネルギー フラックス無視)

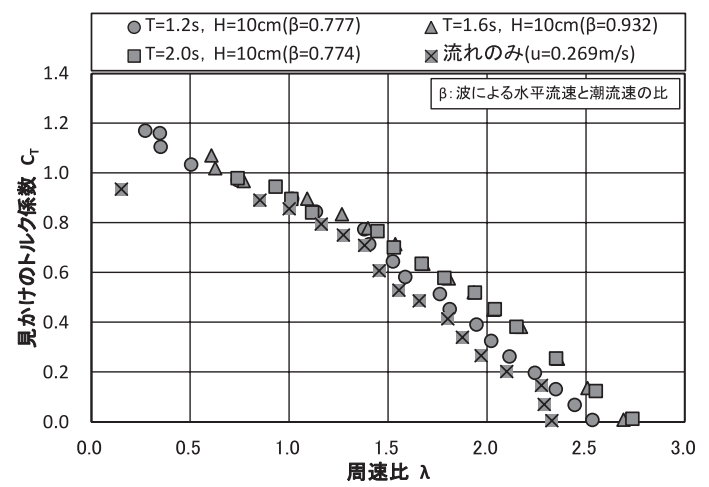

図-16 波と流れが作用するときのトルク係数（波のエネルギ ーフラックス無視）

しく低下する傾向にある.

図-15，16は，潮流エネルギーの取得を主体として，潮 流発電装置に波が副次的に作用するものとして，その影 響度を評価した結果である。すなわち，波と流れが作用 するときでも，変換効率の算定に流れのパワーのみを考 慮する方法（見かけの変換効率）, トルク係数の推定に潮 流による流体力のみを考慮する方法（見かけのトルク倸 数）である.
なお，図中にはパラメータとして線形波動理論による 水面に打ける水粒子水平速度と潮流速の比を示す．図-15 から, 潮流発電装置としての変換効率（見かけの変換効 率）は，波が副次的に作用しても流れのみの場合と同程 度，または増大する傾向にあり，潮流発電において波の 影響は加勢するように現れることが分かる。その増加割 合は作用波高によって変化するが，本実験の範囲では 1 2割程度である．図-16は，波と流れが作用するときの見 かけのトルク係数の結果である. 変換効率と同様に, 波 が副次的に作用しても流れのみの場合と同程度，または 増大寸る傾向にあり，やはり潮流発電に扔いて波の影響 は加勢するように現れることが分かる.

\section{5. 結語}

（1）増速装置付き直立型水車に波のみが作用するときの工 ネルギー変換効率は，10\%以下と低く，水車後部に反 射壁を設置するなどの改善策を考える必要がある。

（2）並列配置した増速装置付き直立型水車を透過性防波 堤とするとき，その波浪制御効果は水車の回転状況 に依存せず，装置の左右の開口部に依存する傾向が 強い.

（3）サボニウス式直立型水車では，渦流型流向制御板を 導入することで, 潮流エネルギー変換効率は $45 \%$ 程 度と約 3 倍程度まで改善される。また，回転力も 4 倍 以上と大きくなり, 流向制御装置は非常に効果的で ある。

（4）波と流れが作用する場合，波のエネルギーも含めて のエネルギー変換効率は，流れのみが作用する場合 と比較して，著しく低下する傾向にある.

（5）潮流発電装置としての見かけの変換効率（波のエネ ルギー無視，流れのみを対象）は，波が副次的に作 用しても増大する傾向にあり, 潮流発電において波 の影響は加勢するように現れる．その増加割合は作 用波高により変化するが，本実験の範囲内では 1 ～ 割程度である。

\section{参 考 文 献}

井内国光·中村孝幸·青山善行·浦中光太 (2012): 来島海峡の島 まわりを想定した潮流発電用水車の効率的な配置法に関する 研究, 土木学会論文集 B2 (海岸工学), Vol. 68, No. 2, pp. 1281-1285

牛山 泉 (2002): 風車工学入門, 森北出版, pp.48-86.

合田良実·鈴木康正・岸良安治・菊池治 (1976) : 不規則波実験に 拈ける入.反射波の分離推定法, 港湾技研資料, No248.

中村孝幸·阿部洋士· Firman Husain •井内國光 (2013): 潮流発電の 高効率化のための新型流向制御板に関する研究, 土木学会 論文集B3 (海洋開発), Vol. 69, No. 2 (印刷中)

中村孝幸·青山善行·浦中光太・安井 孝・二宮一成 $(2011)$ : 潮 流エネルギー変換のための直立型水車に関する研究, 土木学 会論文集B3 (海洋開発)，Vol.67, No. 2, pp. 184-189. 